\title{
YM-254890, a Novel Platelet Aggregation Inhibitor Produced by
}

\section{Chromobacterium sp. QS3666}

\author{
Masatoshi Taniguchi ${ }^{*}$, KoJI Nagal ${ }^{\dagger}$, Nakako AraO $^{\dagger}$, Tominisa KaWasaki, \\ Tetsu Saito, Yumiko Moritani, Jun Takasaki, Kazumi Hayashi, \\ Shigeo FujIta, Ken-ICHI SuZUKI ${ }^{\dagger}$ and Shin-ICHI TsuKamoto \\ Institute for Drug Discovery Research, Yamanouchi Pharmaceutical Co., Ltd., \\ 21, Miyukigaoka, Tsukuba-shi, Ibaraki 305-8585, Japan \\ ${ }^{\dagger}$ Microbiology Laboratories, Institute for Drug Discovery Research, \\ Yamanouchi Pharmaceutical Co., Ltd., \\ 1-1-8 Azusawa, Itabashi-Ku, Tokyo 174-8511, Japan
}

(Received for publication December 4, 2002)

\begin{abstract}
A novel platelet aggregation inhibitor, YM-254890, was isolated from the culture broth of strain QS3666. This strain was isolated from a soil sample collected at Okutama, Tokyo, Japan, and was identified as Chromobacterium sp. by morphological and physiological criteria. YM254890 was purified from the culture supernatant by solvent extraction, ODS and silica gel flash chromatography, followed by preparative HPLC. YM-254890 inhibited ADP-induced platelet aggregation in human platelet-rich plasma with an $\mathrm{IC}_{50}$ value below $0.6 \mu \mathrm{m}$ by blocking the $\mathrm{P}_{2} \mathrm{Y}_{1}$ receptor-signal transduction pathway.
\end{abstract}

Platelets play a crucial role in thrombus formation particularly in the arterial system ${ }^{1)}$. When the vascular endothelium is ruptured, platelets adhere to subendothelial components such as collagen, and this induces platelet aggregation. The adherent platelets spread over the surface and are stimulated to release their dense granule contents including $\mathrm{ADP}$, thromboxane $\mathrm{A}_{2}$ and serotonin. These agonists then activate surrounding platelets, leading to thrombus formation. This process underlies various thromboembolic diseases such as unstable angina, myocardial infarction, stroke and peripheral arterial occlusive diseases. Antiplatelet drugs such as aspirin and ticlopidine inhibit platelet activation and may be useful in the treatment of these diseases ${ }^{2}$. However, since these drugs remain insufficient for the prevention of thrombosis, new types of antiplatelet agents are required ${ }^{3)}$.

In the course of screening for platelet aggregation inhibitors, YM-254890 (Fig. 1) was found from the culture broth of Chromobacterium sp. QS3666 . In this paper, we describe the taxonomy, fermentation, isolation and biological properties of YM-254890. The physico-chemical properties and structure elucidation of YM-254890 will be reported elsewhere.

Fig. 1. Structure of YM-254890.<smiles>C=C(C(=O)NC(C)C(=O)N(C)C(C)C(=O)NC(C(=O)N(C)C(C(=O)OC(C)C(NC(C)=O)C(=O)OC(Cc1ccccc1)C(=O)N(C)C(C)C)C(OC(=O)C(NC(C)=O)C(O)C(C)C)C(C)C)C(C)C)C(O)C(C)C</smiles>

* Corresponding author: taniguti@yamanouchi.co.jp 


\section{Material and Methods}

\section{Taxonomic Studies}

The producing bacterial strain QS3666 was isolated from a soil sample collected at Okutama, Tokyo, Japan. Examination of growth on various media, and tests of physiological characteristics, were based on the methods of COWAN $^{4)}$ and SNEATH ${ }^{5)}$. The morphology of cells grown on meat extract agar at $28^{\circ} \mathrm{C}$ for 24 hours was studied with an optical (OPTIPHOT-2, Nikon) and an atomic force microscope (Nanoscope III, Digital Instruments). Isoprenoid quinones were extracted with $\mathrm{CHCl}_{3}-\mathrm{MeOH}$ (2: $1)^{6)}$ and analyzed by mass spectroscopy (LC/ESI-MS and EI-MS). The guanine plus cytosine $(\mathrm{G}+\mathrm{C})$ content of the DNA was determined by the method of MEsBAH et al. ${ }^{7)}$. 16S rRNA gene sequencing was performed with the MicroSeq 16S rRNA Gene Kit (Applied Biosystems) according to the manufacturer's instructions. All sequences were analyzed with the ABI PRISM 377 DNA sequencer (Applied Biosystems) and compared with the MicroSeq 16S rRNA sequence database.

\section{Platelet Aggregation}

Platelet-rich plasma was prepared by centrifugation of citrate-anticoagulated blood $(3.8 \%$ sodium citrate $:$ blood $=$ $1: 9)$ from healthy human volunteers who had not been on any medication for two weeks preceding the experiments. Platelet aggregation in human platelet-rich plasma was measured using an aggregometer (Hema Tracer 212, MC Medical) by recording the increase in light transmission through a stirred suspension maintained at $37^{\circ} \mathrm{C}$ for 7 minutes. Platelet aggregation in platelet-rich plasma $(3 \times$ $\left.10^{5} / \mu \mathrm{l}\right)$ was induced by $\operatorname{ADP}(2,5$ and $20 \mu \mathrm{M})$. Inhibition was calculated by dividing the maximum rate of decrease in absorbance of a mixture containing test sample by the maximum rate in the buffer control. The $\mathrm{IC}_{50}$ values were calculated from each inhibition curve.

\section{Intracellular Calcium Mobilization}

$\mathrm{C}_{6-15}$ cells $^{8)}$, rat glioma cell line, transfected with human $\mathrm{P} 2 \mathrm{Y}_{1}$ receptor cDNA were seeded into 96 well black clear tissue culture plates 24 hours before assay. The cells were loaded for 1 hour at $37^{\circ} \mathrm{C}$ with $4 \mu \mathrm{M}$ Fluo-3, AM (Molecular Probes) in Dulbecco's Modified Eagle Medium containing 10\% FBS and $2.5 \mathrm{~mm}$ probenecid (Sigma). After washing with Hanks Balanced Salt Solution (GIBCO BRL) and $20 \mathrm{~mm}$ HEPES containing $2.5 \mathrm{~mm}$ probenecid, transient changes in intracellular calcium concentration caused by 2MeSADP (2-methylthioadenosine 5'-diphosphate) were monitored using the FLIPR system (Molecular Devices).
Table 1. Morphological characteristics of strain QS3666.

\begin{tabular}{ll}
\hline Gram stain & Negative \\
Cell shape & Rod \\
Cell size & $0.7-0.8 \times 1.7-2.2 \mu \mathrm{m}$ \\
Spore formation & Negative \\
Color of colony & Pale yellowish brown \\
Motility & Positive \\
Flagella & Peritrichous \\
\hline
\end{tabular}

Test sample was added 5 minutes before addition of 2MeSADP. Data were obtained by the maximum fluorescence counts after addition of the agonist.

\section{Results and Discussion}

Taxonomy of the Producing Strain

The morphological characteristics of strain QS3666 are summarized in Table 1. QS3666 is a motile Gram-negative rod $(0.7 \sim 0.8 \times 1.7 \sim 2.2 \mu \mathrm{m})$ with peritrichous flagellae. Colonies on meat extract agar are circular and pale yellowish brown with smooth or rugose surface.

Physiological characteristics are listed in Tables 2 and 3. It is a facultative anaerobe and the oxidation-fermentation test revealed it to be of fermentative type. It grows between 15 and $32^{\circ} \mathrm{C}$ with optimal growth from 20 to $28^{\circ} \mathrm{C}$, and has a $\mathrm{pH}$ range of 5.0 to 9.0. It does not produce violet pigment and gives positive results for oxidase, catalase, nitrate reduction, and gelatin liquefaction. Voges-Proskauer reaction, indole production, lysine decarboxylase, ornithine decarboxylase, esculin hydrolysis, and deoxyribonuclease are negative. Acid is formed from D-glucose and D-fructose. The $\mathrm{G}+\mathrm{C}$ content of its DNA is $66.1 \mathrm{~mol} \%$. The predominant isoprenoid quinone type is Q-8.

BERGEY's Manual of Systematic Bacteriology (Vol. 1) and Bergey's Manual of Determinative Bacteriology (9th edition) ${ }^{9)}$ indicate that QS3666 belongs to the genus Chromobacterium. A comparison of the physiological characteristics of strain QS3666 and Chromobaterium violaceum is shown in Table 4. Strain QS3666 differs from C. violaceum in its ability to grow at $37^{\circ} \mathrm{C}$ as well as in producing acid from trehalose and mannose. QS3666 and C. violaceum are $98.11 \%$ similar in their $16 \mathrm{~S}$ rRNA 
Table 2. Physiological characteristics of strain QS3666.

\begin{tabular}{|c|c|c|c|}
\hline Nitrate reduction & Positive & Tween 80 esterase & Positive \\
\hline Denitrification & Positive & Starch hydrolysis & Negative \\
\hline Methyl red test & Negative & Gelatin liquefaction & Positive \\
\hline Voges-Proskauer test & Negative & Esculin hydrolysis & Negative \\
\hline Production of & & Lysine decarboxylase & Negative \\
\hline Indole & Negative & Ornithine decarboxylase & Negative \\
\hline $\mathrm{H}_{2} \mathrm{~S}$ & Negative & Arginine dihydrolase & Positive \\
\hline Utilization of & & Range of growth & \\
\hline Citrate & Positive & Temperature & $15-32^{\circ} \mathrm{C}$ \\
\hline $\mathrm{NaNO}_{3}$ & Negative & (Optimum) & $20-28^{\circ} \mathrm{C}$ \\
\hline$\left(\mathrm{NH}_{4}\right)_{2} \mathrm{SO}_{4}$ & Positive & $\mathrm{pH}$ & $5.0-9.0$ \\
\hline Violet pigment & Negative & (Optimum) & $5.0-6.0$ \\
\hline$\beta$-Galactosidase & Negative & Facultative anaerobes & Positive \\
\hline Urease & Negative & O-F test & Fermentative \\
\hline Oxidase & Positive & Growth in $6 \% \mathrm{NaCl}$ & Negative \\
\hline Catalase & Positive & $\mathrm{Mol} \% \mathrm{G}+\mathrm{C}$ of DNA & 66.1 \\
\hline DNase & Negative & Quinone type & Q-8 \\
\hline
\end{tabular}

Table 3. Utilization of carbon sources and formation of acid by strain QS3666.

\begin{tabular}{lcc}
\hline & Acid formation & Utilization \\
\hline L-Arabinose & - & - \\
D-Xylose & - & - \\
D-Glucose & + & + \\
D-Mannose & - & + \\
D-Fructose & + & - \\
Sucrose & - & - \\
Inositol & - & - \\
Rhamnose & N.T. & - \\
Raffinose & N.T. & - \\
D-Mannitol & - & - \\
D-Galactose & - & - \\
Maltose & - & + \\
Toleharose & - & - \\
Lactose & - & - \\
D-Sorbitol & - & - \\
Salicin & N.T. & - \\
Melibiose & N.T. & - \\
Glycerol & - & + \\
Starch & - & + \\
Xanthine & N.T. & - \\
Chitin & N.T. & - \\
\hline & &
\end{tabular}

sequences. In the light of these results, QS3666 was classified and designated as Chromobacterium sp. QS3666. Strain QS3666 has been deposited in the International Patent Organism Depositary, National Institute of Advanced Industrial Science and Technology, Ibaraki, Japan, with accession no. FERM P-18672.

\section{Fermentation}

A slant culture of QS3666 grown on Bennett's agar was used to inoculate a 500-ml Erlenmeyer flask containing $100 \mathrm{ml}$ of a seed medium consisting of glucose $1 \%$, potato starch 2\%, Polypeptone (Nihon Pharmaceutical) 0.5\%, yeast extract $0.5 \%$ and $\mathrm{CaCO}_{3} \quad 0.4 \%$ (pH 7.0). After incubation at $28^{\circ} \mathrm{C}$ for three days on a rotary shaker at 220 $\mathrm{rpm}$, the seed culture was inoculated into each of twenty five 500-ml Erlenmeyer flasks containing $100 \mathrm{ml}$ of a production medium consisting of glycerol $2 \%$, glucose $0.5 \%$, Polypepton $0.5 \%$, meat extract $0.5 \%$, yeast extract $0.1 \%$ and $\mathrm{NaCl} 0.1 \%(\mathrm{pH} 6.5)$. Fermentation was carried out at $28^{\circ} \mathrm{C}$ for three days on a rotary shaker at $220 \mathrm{rpm}$.

\section{Isolation}

The procedure used to purify YM-254890 is outlined in Fig. 2. The fermentation broth (2.5 liters) was filtered, and 
Table 4. Comparison of strain QS3666 with Chromobacterium violaceum.

\begin{tabular}{lcc}
\hline & QS3666 & C. violaceum $^{a}$ \\
\hline Growth at $4^{\circ} \mathrm{C}$ & - & - \\
Growth at $37^{\circ} \mathrm{C}$ & - & + \\
Arginine dihydrolase & + & $\mathrm{d}(50)$ \\
Acid from: & + & + \\
Glucose & + & + \\
Fructose & - & + \\
Trehalose & - & {$[+](80)$} \\
Mannose & & \\
\hline
\end{tabular}

${ }^{a}$ Data for C. violaceum are derived from BERGEY's Manual of Systematic Bacteriology (Vol. 1).

Symbols: + , all strains positive; $[+]$, positive in $80 \%$ or more strains; $d$, positive in $31-79 \%$ of strains; [-], positive in $30 \%$ or fewer strains; -, negative in all strains. Numbers in parentheses indicate the $\%$ of strains giving a positive reaction.

Fig. 2. Purification procedure of YM-254890.

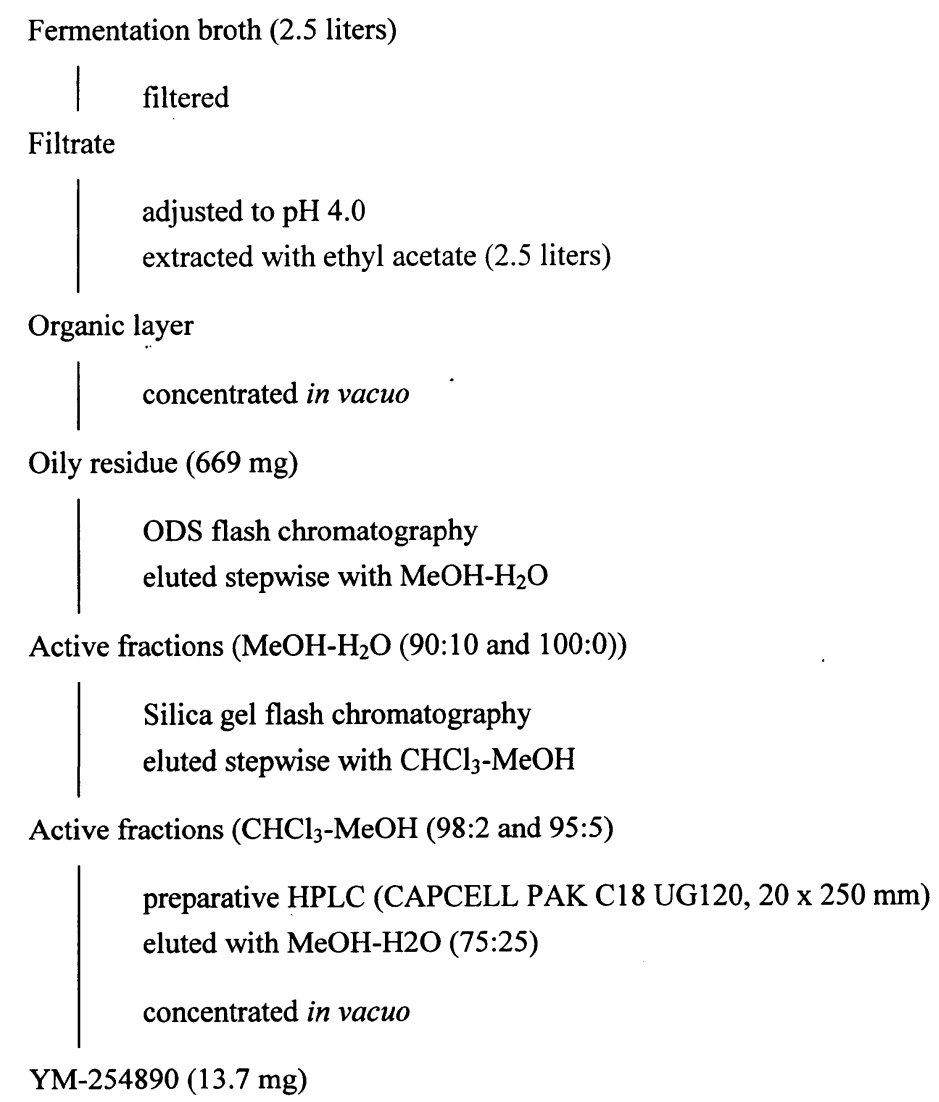


Fig. 3. Effect of YM-254890 on ADP-induced platelet aggregation in human platelet-rich plasma.

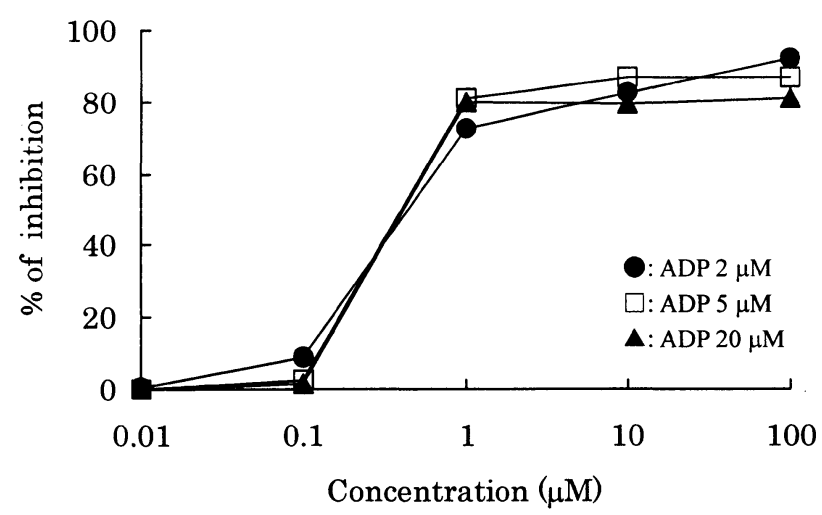

the filtrate adjusted to $\mathrm{pH} 4.0$ with $1 \mathrm{~N} \mathrm{HCl}$ and extracted with 2.5 liters of EtOAc. The organic layer was dried over anhydrous $\mathrm{Na}_{2} \mathrm{SO}_{4}$ and concentrated in vacuo to give a brown extract $(669 \mathrm{mg})$. This oily extract was subjected to ODS flash chromatography (YMC-GEL ODS-A 120 $130 / 70,40 \times 55 \mathrm{~mm}, \mathrm{YMC}$ ) and eluted with a step gradient from $40 \%$ to $100 \% \mathrm{MeOH}$. The fractions eluted with $90 \%$ and $100 \% \mathrm{MeOH}$ were combined and concentrated to dryness in vacuo $(278 \mathrm{mg})$. The yellow residue was subjected to Silica gel flash chromatography (Kieselgel 60 $0.040 \sim 0.063 \mathrm{~mm}, 40 \times 45 \mathrm{~mm}, \mathrm{MERCK})$, with elution by a step gradient of $\mathrm{CHCl}_{3}-\mathrm{MeOH}$ solvent system. The active fractions eluted with $\mathrm{CHCl}_{3}-\mathrm{MeOH}(98: 2$ and $95: 5)$ were evaporated to dryness $(30 \mathrm{mg})$. Finally the residue was purified by preparative HPLC (CAPCELL PAK C18 UG120, $20 \times 250 \mathrm{~mm}$, Shiseido) with $\mathrm{MeOH} / \mathrm{H}_{2} \mathrm{O}(75: 25)$ at a flow rate of $8 \mathrm{ml} / \mathrm{minute}$ to yield $13.7 \mathrm{mg}$ of YM254890 as a white powder.

\section{Biological Properties}

The antiplatelet activities of YM-254890 are shown in Fig. 3. YM-254890 inhibited platelet aggregation induced by $\operatorname{ADP}(2,5$ and $20 \mu \mathrm{M})$ in human platelet-rich plasma with $\mathrm{IC}_{50}$ values of $0.37,0.39$ and $0.51 \mu \mathrm{M}$. It is well established that ADP mediates platelet aggregation via two $\mathrm{G}$ protein-coupled receptors, $\mathrm{P} 2 \mathrm{Y}_{1}$ and $\mathrm{P} 2 \mathrm{Y}_{12}{ }^{10)}$. The $\mathrm{P} 2 \mathrm{Y}_{1}$ receptor is responsible for the mobilization of intracellular calcium stores via the $\mathrm{Gq}$ pathway, while the $\mathrm{P} 2 \mathrm{Y}_{12}$ receptor is coupled to $\mathrm{Gi}$ and adenylyl cyclase inhibition. We therefore examined the effect of YM-254890 on the
Fig. 4. Effect of YM-254890 on 2MeSADPinduced intracellular calcium mobilization in $\mathrm{P} 2 \mathrm{Y}_{1}-\mathrm{C}_{6-15}$ cells.

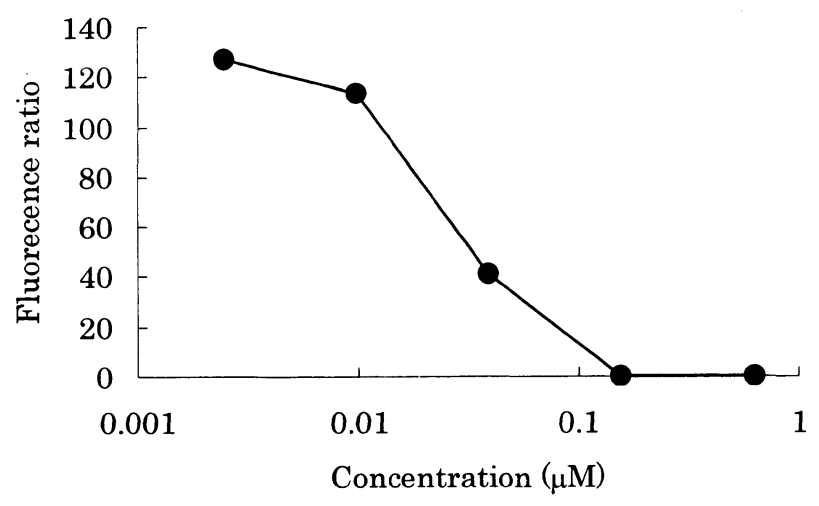

$\mathrm{P} 2 \mathrm{Y}_{1}$ and $\mathrm{P} 2 \mathrm{Y}_{12}$ signal transduction pathways using $\mathrm{C}_{6-15}$ cells stably expressing the human $\mathrm{P}_{2} \mathrm{Y}_{1}$ or $\mathrm{P} 2 \mathrm{Y}_{12}$ receptors. Stimulation of $\mathrm{P}_{2} \mathrm{Y}_{1}-\mathrm{C}_{6-15}$ cells by $2 \mathrm{MeSADP}$ leads to increases in intracellular calcium mobilization. In this assay, YM-254890 inhibited the increase in $\left[\mathrm{Ca}^{2+}\right]_{i}$ with an $\mathrm{IC}_{50}$ value of $0.031 \mu \mathrm{M}$ (Fig. 4). In contrast, 2MeSADPinduced inhibition of forskolin-stimulated adenylyl cyclase activity in $\mathrm{P} 2 \mathrm{Y}_{12}-\mathrm{C}_{6-15}$ cells was unaffected by $\mathrm{YM}-254890$ at $40 \mu \mathrm{M}$ (data not shown). These results suggest that YM254890 inhibits platelet aggregation induced by ADP by blocking the $\mathrm{P} 2 \mathrm{Y}_{1}$ signal transduction pathway. Further pharmacological studies and investigation of the mechanism of action of this compound are now underway.

\section{References}

1) Paскham, M. A.: Role of platelets in thrombosis and hemostasis. Can. J. Physiol. Pharmacol. 72: 278 284, 1994

2) SCHrÖr, K.: Antiplatelet drugs - a comparative review. Drugs 50: 7 28, 1995

3) Topol, E. J.; T. V. Byzova \& E. F. Plow: Platelet GPIIbIIIa blockers. Lancet 353: 227 231, 1999

4) Cowan, S. T. (Ed.): Manual for the identification of medical bacteria. Cambridge University Press, 1974

5) Sneath, P. H. A.: Genus Chromobacterium Bergonzini 1881, 153. In BERGEY's Manual of Systematic Bacteriology. Vol. 1., Eds., N. R. KRIEG \& J. G. Holt, pp. 580 582, Williams \& Wilkins Co., Baltimore, 1984

6) Collins, M. D.; T. Pirouz, M. Goodfellow \& D. E. MINNIKIN: Distribution of menaquinones in actinomycetes and corynebacteria. J. Gen. Microbiol. 100: 221 230, 1977

7) Mesbah, M.; U. Premachandran \& W. B. Whitman: Precise measurement of $\mathrm{G}+\mathrm{C}$ content of deoxy- 
ribonucleic acid by high-performance liquid chromatography. Int. J. Syst. Bacteriol. 39: 159 167, 1989

8) Takasaki, J.; M. Kamohara, T. Saito, M. Matsumoto, S. Matsumoto, T. Ohishi, T. Soga, H. Matsushime \& K. FURUICHI: Molecular cloning of the platelet P2T $\mathrm{AC}_{\mathrm{AC}}$ ADP receptor: pharmacological comparison with another ADP receptor, the $\mathrm{P}_{2} \mathrm{Y}_{1}$ receptor. Mol. Pharmacol. 60: 432
439, 2001

9) Bergey's Manual of Determinative Bacteriology 9th Edition, Ed., J. G. HolT et al., Williams \& Wilkins Co., Baltimore, USA, 1994

10) GACHET, C.: ADP receptors of platelets and their inhibition. Thromb. Haemost. 86: 222 232, 2001 